\title{
ABORSI DALAM TINJAUAN ETIKA KESEHATAN, PERSPEKTIF ISLAM, DAN HUKUM DI INDONESIA
}

\author{
Anik Listiyana \\ Jurusan Biologi Fakultas Sains dan Teknologi UIN Maliki Malang \\ Email: anik_listiyana@yahoo.co.id \\ Telepon: 081330622252
}

\begin{abstract}
Abortion is still a controversial problem in Indonesian society recently. Statistical data which are revealed by National Board for family Planning Coordination show that around 2.000.000 cases of abortion practiced in Indonesia every year. The debate on its legality to be practiced, particularly the four schools of sect, agree to put abortion as an unlawful practice. Therefore, abortion generally is a cruel action, against humanity values and it also against law and religious tenets. However, regardless all those aspects, its legal status should be studied specifically and deeply because it is not a single action. This sort of action has various kinds of action based on its conditional consideration. This writing aims at discussing abortion by looking at Indonesian legal regulation through criminal law and health regulation.
\end{abstract}

Aborsi masih menjadi masalah yang ckontroversial pada masyarakat Indonesia saat ini. Data statistik yang dikeluarkan oleh Badan Koordinasi Keluarga Berencana Nasional menunjukkan bahwa terdapat 2000.000 kasus aborsi terjadi tiap tahun. Perdebatan terhadap status hukum aborsi untuk dilakukan, terutama bagi empat madzhab, menyepakati bahwa aborsi adalah tindakan yang diharamkan. Oleh karena itu, aborsi pada umumnya adalah tindakan kejam, bertentangan dengan nilai-nilai kemanusiaan, bertentangan dengan hukum dan ajaran agama. Akan tetapi, tanpa mempertimbangkan seluruh aspek tersebut, status hukum dari aborsi harus dikaji secara khusus dan mendalam karena aborsi bukanlah satu bentuk tindakan. Praktek aborsi memiliki beberapa bentuk berdasarkan pertimbangan kondisi yang menyertainya. Tujuan dari tulisan ini adalah 
mendiskusikan aborsi dengan melihat perundang-undangan di Indonesia melalui KUHP dan Undang-Uundang kesehatan.

Keywords: aborsi, etika kesehatan, prespektif islam, hukum di indonesia

\section{Pendahuluan}

Data statistik BKBN (Badan Koordinasi Keluarga Berencana Nasional) menunjukkan bahwa sekitar 2.000.000 kasus aborsi terjadi setiap tahun di Indonesia. Untuk kasus aborsi di luar negeri khususnya di Amerika data-datanya telah dikumpulkan oleh dua badan utama, yaitu Federal Centers for Disease Control (CDC) dan Alan Guttmacher Institute (AGI) yang menunjukkan hampir 2 juta jiwa terbunuh akibat aborsi. Jumlah ini jauh lebih banyak dari jumlah nyawa manusia yang dibunuh dalam perang manapun dalam sejarah negara itu. Begitu juga lebih banyak dari kematian akibat kecelakaan, maupun akibat penyakit. (http://aborsi. net/info/statistik-aborsi.html ).

Menurut penelitian Komnas Perlindungan Anak di 33 provinsi pada bulan Januari-Juni 2008, menyimpulkan empat hal; pertama, 97 persen remaja SMP dan SMA pernah menonton film porno; kedua, 93,7 persen remaja SMP dan SMA pernah ciuman, meraba alat kelamin dan oral seks; ketiga, remaja SMP tidak perawan; dan keempat, 21,2 persen remaja mengaku pernah aborsi. (Arjuna Nusantara:23/04/2012. Opini Harian Pagi Padang Ekspress).

Di negara-negara yang tidak mengizinkan aborsi seperti Indonesia, banyak perempuan terpaksa mencari pelayanan aborsi tidak aman karena tidak tersedianya pelayanan aborsi aman atau biaya yang ditawarkan terlalu mahal. Pada remaja perempuan kendala terbesar adalah rasa takut dan tidak tahu harus mencari konseling. Hal ini menyebabkan penundaan remaja mencari pertolongan pelayanan aman, dan sering kali terperangkap di praktek aborsi tidak aman. WHO memperkirakan ada 4,2 juta aborsi dilakukan per tahun, 750.000 - 1,5 juta dilakukan di Indonesia, 2.500 orang diantaranya berakhir dengan kematian. Survei Kesehatan Rumah Tangga (SKRT) tahun 1995 : aborsi berkontribusi 11,1 \% terhadap Angka kematian Ibu (AKI). (http://www.kesrepro.info).

Selama beberapa tahun terakhir ini di Amerika Serikat terjadi ratarata 1,5 juta abortus pertahun. Debat moral tentang abortus terbukti menjadi 
salah satu diskusi yang paling memecah belah bangsa dan sejarah negara Amerika Serikat.(Shannon, 1995:41). Menurut Dr. Ravinder Dhallan, ketua, CEO dan pendiri Ravgen Inc. seperti dilansir Health Day, sekitar 5\% wanita yang diperkosa hamil, sehingga diperkirakan menghasilkan 32.000 kehamilan yang tidak diinginkan setiap tahunnya. Tes yang ada sebelumnya tidak dapat dilakukan sebelum usia kehamilan mencapai 10 - 15 minggu. Sayangnya $80 \%$ aborsi sudah terjadi saat usia kehamilan belum mencapai 10 minggu. Menurut Dhallan, tes seperti ini akan mencegah beberapa wanita membatalkan keputusan untuk menggugurkan bayinya sebelum mengetahui bayi yang dikandung dihasilkan dari perkosaan ataukah hubungan seks dengan pasangan yang dicintai. (http://health. detik.com/read/2012/05/03)

Saat ini aborsi masih merupakan masalah kontroversial di masyarakat Indonesia. Namun terlepas dari kontorversi tersebut, aborsi diindikasikan merupakan masalah kesehatan masyarakat karena memberikan dampak padakesakitan dan kematianibu. Sebagaimana diketahuipenyebab utama kematian ibu hamil dan melahirkan adalah perdarahan, infeksi dan eklampsia. Namun sebenarnya aborsi juga merupakan penyebab kematian ibu, hanya saja muncul dalam bentuk komplikasi perdarahan dan sepsis . Akan tetapi, kematian ibu yang disebabkan komplikasi aborsi sering tidak muncul dalam laporan kematian, tetapi dilaporkan sebagai pendarahan atau sepsis. Hal itu terjadi karena hingga saat ini aborsi masih merupakan masalah kontroversial di masyarakat.

\section{Pengertian Aborsi}

Dalam kamus Inggris-Indonesia Jhon M. Echols dan Hasan Shadily aborsi yang diserap dari bahasa inggris abortion yang berasal dari bahasa latin yang berarti pengguguran kandungan atau keguguran. Menurut Maria Ulfah Anshor (2006: 32) aborsi dalam literatur fikih berasal dari bahasa arab al-ijhad, merupakan masdhar dari ajhada atau juga dalam istilah lain bisa disebut dengan isqath al-haml, keduanya mempunyai arti perempuan yang melahirkan secara paksa dalam keadaan belum sempurna penciptaannya. Gugur kandungan atau aborsi (bahasa Latin: abortus) adalah berhentinya kehamilan sebelum usia kehamilan 20 minggu yang mengakibatkan kematian janin. Apabila janin lahir selamat (hidup) sebelum 38 minggu namun setelah 20 minggu, maka istilahnya adalah kelahiran prematur. 
Dalam ilmu kedokteran, ada istilah-istilah yang biasa digunakan untuk membedakan aborsi, yaitu:

1. Spontaneous abortion: gugur kandungan yang disebabkan oleh trauma kecelakaan atau sebab-sebab alami.

2. Induced abortion atau procured abortion: pengguguran kandungan yang disengaja. Termasuk di dalamnya adalah:

a. Therapeutic abortion: pengguguran yang dilakukan karena kehamilan tersebut mengancam kesehatan jasmani atau rohani sang ibu, kadang-kadang dilakukan sesudah pemerkosaan.

b. Eugenic abortion: pengguguran yang dilakukan terhadap janin yang cacat.

c. Elective abortion: pengguguran yang dilakukan untuk alasanalasan lain.

Dalam bahasa sehari-hari, istilah "keguguran" biasanya digunakan untuk spontaneous abortion, sementara "aborsi" digunakan untuk induced abortion. (http://id.wikipedia.org)

Menurut K. Bertens, (2002) Abortus profocatus adalah istilah Latin yang secara resmi dipakai dalam kalangan kedokteran dan hukum. Maksudnya adalah dengan sengaja mengakhiri kehidupan kandungan dalam rahim seseorang perempuan hamil. Untuk menunjukkan pengguguran kandungan, istilah yang paling populer sekarang adalah "aborsi" yang tentunya dibentuk berdasarkan kata Inggris abortion.

Menurut The World Book Encyclopedia yang dikeluarkan $A$ Collector's Printing hal. 14 a tahun 1976, aborsi adalah berakhirnya kehamilan seseorang sebelum janin bayi dapat hidup diluar kandungan, kemudian selanjutnya menurut The New Lexicon Webster's Encyclopedia Dictionary Of The English Language Deluxe Edition, hal. 3, aborsi adalah pengeluaran janin bayi dari rahim baik secara paksa maupun secara tidak sengaja. (http://stupidforwriting.blogspot.com)

Menurut Kamus Besar Bahasa Indonesia Edisi kedua hal 2, aborsi adalah pengguguran kandungan. Sedangkan menurut kamus istilah kedokteran (Danis) halaman 10 abortion (aborsi) adalah pengeluaran hasil konsepsi atau pembuahan sebelum janin dapat hidup di luar tubuh ibunya dari uterus sebelum janin viabel. 


\section{Aborsi Dalam Tinjauan Etika Kesehatan}

Menurut medis aborsi dibagi menjadi dua, yaitu:

1. Abortus spontanea (aborsi spontan)

Abortus spontanea merupakan abortus yang berlangsung tanpa tindakan. Menurut Aslim (1988) aborsi spontan dibedakan sebagai berikut:

a. Abortus imminens (threatened abortion), Peristiwa terjadinya perdarahan dari uterus pada kehamilan sebelum 20 minggu, dimana hasil konsepsi masih dalam uterus, dan tanpa adanya dilatasi serviks. Pengertian Abortus imminen adalah perdarahan bercak yang menunjukkan ancaman terhadap kelangsungan suatu kehamilan. Dalam kondisi seperti ini kehamilan masih mungkin berlanjut atau dipertahankan. Abortus imminen adalah perdarahan pervaginam pada kehamilan kurang dari 20 minggu, tanpa tanda-tanda dilatasi serviks yang meningkat.

b. Abortus Incipiens (inevitable abortion), artinya terdapat gejala akan terjadinya aborsi, namun buah kehamilan masih berada di dalam rahim. Dalam hal demikian kehamilan tidak dapat dipertahankan lagi.

c. Abortus Incompleteus, apabila sebagian dari buah kehamilan sudah keluar dan sisanya masih berada dalam rahim. Pendarahan yang terjadi biasanya cukup banyak, namun tidak fatal, untuk pengobatan perlu dilakukan pengosongan rahim secepatnya.

d. Abortus Completus, yaitu pengeluaran keseluruhan buah kehamilan dari rahim. Keadaan demikian biasanya tidak memerlukan pengobatan.

\section{Abortus provokatus}

Abortus provokatus merupakan jenis abortus yang sengaja dibuat/dilakukan, yaitu dengan cara menghentikan kehamilan sebelum janin dapat hidup di luar tubuh ibu. Pada umumnya bayi dianggap belum dapat hidup diluar kandungan apabila usia kehamilan belum mencapai 28 minggu, atau berat badan bayi kurang dari 1000 gram, walaupun terdapat beberapa kasus bayi dengan berat dibawah 1000 gram dapat terus hidup. Pengelompokan Abortus provokatus secara lebih spesifik: 
a. Abortus Provokatus Medisinalis/Artificialis/Therapeuticus, aborsi yang dilakukan dengan disertai indikasi medik. Di Indonesia yang dimaksud dengan indikasi medik adalah demi menyelamatkan nyawa ibu. Syarat-syaratnya:

- Dilakukan oleh tenaga kesehatan yang memiliki keahlian dan kewenangan untuk melakukannya (yaitu seorang dokter ahli kebidanan dan penyakit kandungan) sesuai dengan tanggung jawab profesi.

- Harus meminta pertimbangan tim ahli (ahli medis lain, agama, hukum, psikologi).

- Harus ada persetujuan tertulis dari penderita atau suaminya atau keluarga terdekat.

- Dilakukan di sarana kesehatan yang memiliki tenaga/ peralatan yang memadai, yang ditunjuk oleh pemerintah.

- Prosedur tidak dirahasiakan.

- Dokumen medik harus lengkap.

(Legalitas aborsi provokatus terapeutik diatur dalam UU No 23/1992 tentang Kesehatan).

b. Abortus Provokatus Kriminalis (Abortus Profocatus Criminalis), aborsi yang sengaja dilakukan tanpa adanya indikasi medik (ilegal) yang lazim dikenal dengan sebutan aborsi/ pengguguran. Biasanya pengguguran dilakukan dengan menggunakan alat-alat atau obat.

WHO memperkirakan per tahun terjadi sekitar 750.000 sampai 1,5 juta kasus aborsi spontan maupun aborsi provokatus. Jumlah ini bisa jauh lebih besar lagi mengingat kejadian aborsi provokatus kriminalis yang tidak mungkin dilaporkan.Aborsi provokatus baik bertujuan terapeutik maupun aborsi kriminalis tidaklah tanpa resiko yang sedikit kendati dilakukan oleh tenaga medis profesional sekalipun, seperti dokter spesialis kebidanan dan kandungan misalnya. Resiko akan menjadi semakin besar jika aborsi, khususnya aborsi kriminalis dilakukan bukan oleh tenaga medis profesional, seperti dilakukan oleh dukun ataupun dilakukan sendiri dengan cara-cara yang tidak aman seperti 
memasukan alat-alat tertentu ataupun zat kimia tertentu yang tidak steril dan bersifat racun ke dalam vagina. Resiko dari tindakan aborsi provokatus tidak hanya mencakup resiko jangka pendek melainkan juga resiko jangka panjang. Resiko jangka pendek yang tersering adalah terjadinya perdarahan yang dapat mengancam jiwa. Resiko lain adalah syok septik akibat tindakan aborsi yang tidak steril yang sering berakhir dengan kematian dan juga kegagalan ginjal sebagai penyerta syok ataupun yang ditimbulkan karena penggunaan senyawa-senyawa racun yang dipakai untuk menimbulkan aborsi, seperti lisol, sabun, phisohex. Resiko jangka panjang yang akan dihadapi oleh seseorang yang melakukan aborsi provokatus adalah kemungkinan terjadinya kehamilan ektopik (kehamilan di luar tempat yang semestinya) pada kehamilan berikutnya akibat kerusakan pada lapisan dalam rahim (endometrium) setelah dilakukan dilatasi (pelebaran secara paksa leher rahim dengan alat khusus) dan kuretase (pengerokan endometrium dengan alat khusus) pada tindakan aborsi. Kerusakan pada endometrium yang diakibatkan dilatasi dan kuretase ini juga meningkatkan resiko terjadinya placenta previa (letak plasenta tidak pada tempat semestinya sehingga mengganggu proses persalinan), aborsi spontan pada kehamilan berikutnya, berat badan bayi lahir rendah sampai kemungkinan terjadinya kemandulan akibat kerusakan yang luas pada endometrium. (http://stupidforwriting.blogspot. com/2009/11/aborsi-secara-medis-dan-moral.html)

\section{Aborsi dalam Prespektif Islam}

Sayyid Sabiq dalam bukunya Fikih Sunnah jilid X: hal 10 mengatakan, bahwa hal yang paling perlu mendapat perhatian diantara hak-hak manusia adalah hak hidup. Karena hal ini adalah hak yang suci, tidak dibenarkan secara hukum dilanggar kemuliaannya dan tidak boleh dianggap remeh eksistensinya.

Sebelum menjelaskan secara mendetail tentang hukum Aborsi, lebih dahulu perlu dijelaskan tentang pandangan umum ajaran Islam tentang nyawa, janin dan pembunuhan, yaitu sebagai berikut; pertama, 
manusia adalah ciptaan Allah yang mulia, tidak boleh dihinakan baik dengan merubah ciptaan tersebut, maupun menguranginya dengan cara memotong sebagian anggota tubuhnya, maupun dengan cara memperjual belikannya, maupun dengan cara menghilangkannya sama sekali yaitu dengan membunuhnya, sebagaiman firman Allah swt :

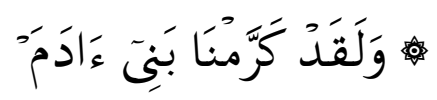

"Dan sesungguhnya Kami telah memuliakan umat manusia "( Qs. al-Isra':70)

Kedua, membunuh satu nyawa sama artinya dengan membunuh semua orang. Menyelamatkan satu nyawa sama artinya dengan menyelamatkan semua orang.

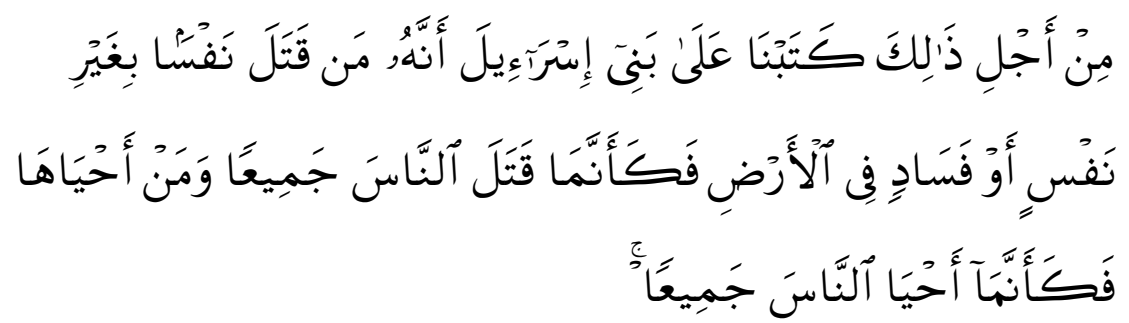

"Oleh Karena itu kami tetapkan (suatu hukum) bagi Bani Israil, bahwa: barangsiapa yang membunuh seorang manusia, bukan Karena orang itu (membunuh) orang lain, atau bukan Karena membuat kerusakan dimuka bumi, Maka seakan-akan dia Telah membunuh manusia seluruhnya dan Barang siapa yang membunuh seorang manusia, maka seakan-akan dia telah membunuh manusia seluruhnya. Dan barang siapa yang memelihara keselamatan nyawa seorang manusia, maka seolah-olah dia telah memelihara keselamatan nyawa manusia semuanya." (Qs. A1 Maidah:32)

Ketiga, dilarang membunuh anak (termasuk janin yang masih dalam kandungan), hanya karena takut miskin. Sebagaimana firman Allah swt :

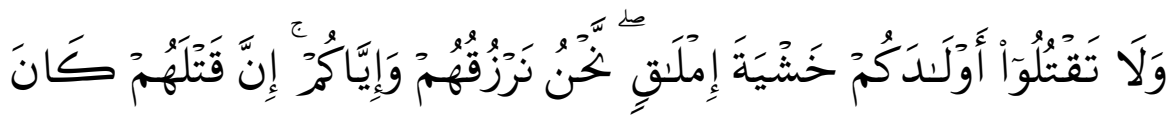




\section{خِطُعًَا كَبيرًا}

"Dan janganlah kamu membunuh anak-anakmu karena takut melarat. Kamilah yang memberi rezeki kepada mereka dan kepadamu juga. Sesungguhnya membunuh mereka adalah dosa yang besar.” (Qs al Isra' : 31)

Keempat, setiap janin yang terbentuk adalah merupakan kehendak Allah swt, sebagaimana firman Allah swt:

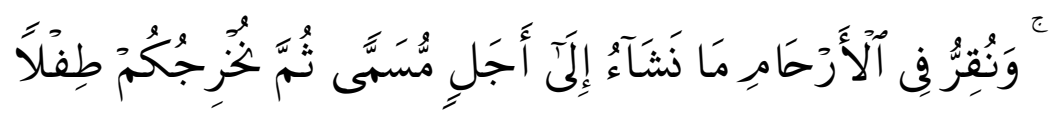

"Selanjutnya Kami dudukan janin itu dalam rahim menurut kehendak Kami selama umur kandungan. Kemudian kami keluarkan kamu dari rahim ibumu sebagai bayi.” (QS al Hajj : 5)

Kelima, larangan membunuh jiwa tanpa hak, sebagaimana firman Allah swt :

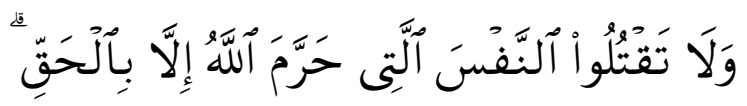

"Dan janganlah kamu membunuh jiwa yang diharamkan Allah melainkan dengan alasan yang benar " ( Qs al Isra' : 33 )

Di dalam teks-teks al Qur'an dan Hadist tidak didapati secara khusus hukum aborsi, tetapi yang ada adalah larangan untuk membunuh jiwa orang tanpa hak, sebagaimana firman Allah swt :

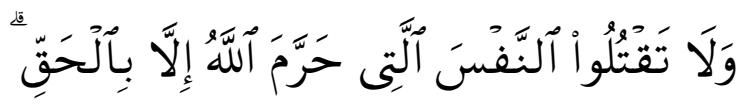

"Dan barang siapa yang membunuh seorang mukmin dengan sengaja, maka balasannya adalah neraka Jahanam, dan dia kekal di dalamnya,dan Allah murka kepadanya dan melaknatnya serta menyediakan baginya adzab yang besar ( Qs An Nisa' : 93 )

Begitu juga hadist yang diriwayatkan oleh Ibnu Mas'ud bahwasanya Rasulullah Saw bersabda :

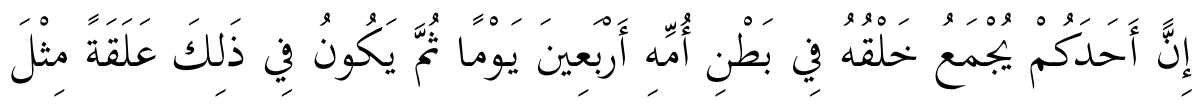




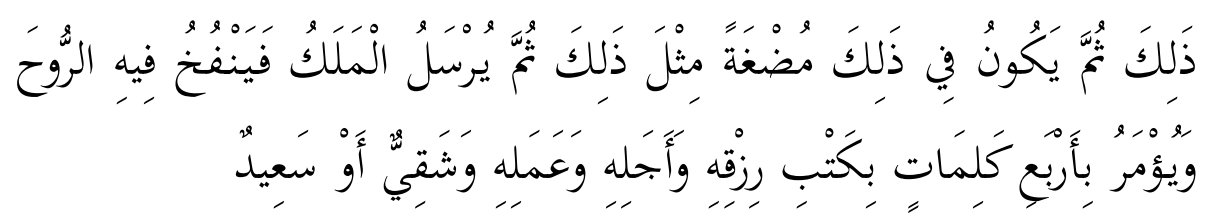

“ Sesungguhnya seseorang dari kamu dikumpulkan penciptaannya di dalam perut ibunya selama empat puluh hari. Setelah genap empat puluh hari kedua, terbentuklah segumlah darah beku. Ketika genap empat puluh hari ketiga, berubahlah menjadi segumpal daging. Kemudian Allah mengutus malaikat untuk meniupkan roh, serta memerintahkan untuk menulis empat perkara, yaitu penentuan rizki, waktu kematian, amal, serta nasibnya, baik yang celaka, maupun yang bahagia. “ (Bukhari dan Muslim )

Untuk mempermudah pemahaman, pembahasan ini bisa dibagi menjadi dua bagian sebagai berikut :

1. Menggugurkan Janin Sebelum Peniupan Roh

Dalam hal ini, para ulama berselisih tentang hukumnya dan terbagi menjadi tiga pendapat

a. Pendapat Pertama

Menggugurkan janin sebelum peniupan roh hukumnya boleh. Bahkan sebagian dari ulama membolehkan menggugurkan janin tersebut dengan obat. Pendapat ini dianut oleh para ulama dari madzhab Hanafi, Syafi'i, dan Hambali. Tetapi kebolehan ini disyaratkan adanya ijin dari kedua orang tuanya.

Mereka berdalil dengan hadist Ibnu Mas'ud di atas yang menunjukkan bahwa sebelum empat bulan, roh belum ditiup ke janin dan penciptaan belum sempurna, serta dianggap benda mati, sehingga boleh digugurkan.

b. Pendapat kedua :

Menggugurkan janin sebelum peniupan roh hukumnya makruh. Dan jika sampai pada waktu peniupan ruh, maka hukumnya menjadi haram.

Dalilnya bahwa waktu peniupan ruh tidak diketahui secara pasti, maka tidak boleh menggugurkan janin jika telah mendekati 
waktu peniupan ruh, demi untuk kehati-hatian . Pendapat ini dianut oleh sebagian ulama madzhab Hanafi dan Imam Romli salah seorang ulama dari madzhab Syafi'i .

c. Pendapat ketiga :

Menggugurkan janin sebelum peniupan roh hukumnya haram. Dalilnya bahwa air mani sudah tertanam dalam rahim dan telah bercampur dengan ovum wanita sehingga siap menerima kehidupan, maka merusak wujud ini adalah tindakan kejahatan. Pendapat ini dianut oleh Ahmad Dardir, Imam Ghozali dan Ibnu Jauzi (Maria Ulfa Anshor, 2006). Adapun status janin yang gugur sebelum ditiup rohnya (empat bulan), telah dianggap benda mati, maka tidak perlu dimandikan, dikafani ataupun disholati. Sehingga bisa dikatakan bahwa menggugurkan kandungan dalam fase ini tidak dikatagorikan pembunuhan, tapi hanya dianggap merusak sesuatu yang bermanfaat.

Ketiga pendapat ulama di atas tentunya dalam batasbatas tertentu, yaitu jika di dalamnya ada kemaslahatan, atau dalam istilah medis adalah salah satu bentuk Abortus Profocatus Therapeuticum, yaitu jika bertujuan untuk kepentingan medis dan terapi serta bukan dalam katagori Abortus Profocatus Criminalis, yaitu yang dilakukan karena alasan yang bukan medis dan melanggar hukum yang berlaku, sebagaimana yang telah dijelaskan di atas.

\section{Menggugurkan Janin Setelah Peniupan Roh}

Secara umum, para ulama telah sepakat bahwa menggugurkan janin setelah peniupan roh hukumnya haram. Peniupan roh terjadi ketika janin sudah berumur empat bulan dalam perut ibu, Ketentuan ini berdasarkan hadist Ibnu Mas'ud di atas. Janin yang sudah ditiupkan roh dalam dirinya, secara otomatis pada saat itu, dia telah menjadi seorang manusia, sehingga haram untuk dibunuh. Hukum ini berlaku jika pengguguran tersebut dilakukan tanpa ada sebab yang darurat. Namun jika ada sebab-sebab darurat, seperti jika sang janin nantinya akan membahayakan ibunya jika lahir nanti, maka dalam hal ini, para ulama berbeda pendapat: 
a. Pendapat Pertama :

Menyatakan bahwa menggugurkan janin setelah peniupan roh hukumnya tetap haram, walaupun diperkirakan bahwa janin tersebut akan membahayakan keselamatan ibu yang mengandungnya. Pendapat ini dianut oleh Mayoritas Ulama.

Dalilnya adalah firman Allah Swt :

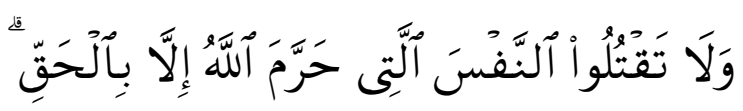

“Dan janganlah kamu membunuh jiwa yang diharamkan Allah (membunuhnya), melainkan dengan suatu (alasan) yang benar. " (Q.S. Al Israa': 33)

Kelompok ini juga mengatakan bahwa kematian ibu masih diragukan, sedang keberadaan janin merupakan sesuatu yang pasti dan yakin, maka sesuai dengan kaidah fiqhiyah: " Bahwa sesuatu yang yakin tidak boleh dihilanngkan dengan sesuatu yang masih ragu.", yaitu tidak boleh membunuh janin yang sudah ditiup rohnya yang merupakan sesuatu yang pasti, hanya karena kawatir dengan kematian ibunya yang merupakan sesuatu yang masih diragukan..

Selain itu, mereka memberikan permitsalan bahwa jika sebuah perahu akan tenggelam, sedangkan keselamatan semua perahu tersebut bisa terjadi jika sebagian penumpangnya dilempar ke laut, maka hal itu juga tidak dibolehkan.

b. Pendapat Kedua :

Dibolehkan menggugurkan janin walaupun sudah ditiupkan roh kepadanya, jika hal itu merupakan satu-satunya jalan untuk menyelamatkan ibu dari kematian. Karena menjaga kehidupan ibu lebih diutamakan dari pada menjaga kehidupan janin, karena kehidupan ibu lebih dahulu dan ada secara yakin, sedangkan kehidupan janin belum yakin dan keberadaannya terakhir. Prediksi tentang keselamatan ibu dan janin bisa dikembalikan kepada ilmu kedokteran, walaupun dalam hal ini tidak mutlak benarnya. (http://www.ahmadzain.com/read/karya-tulis/258/ hukum-aborsi-dalam-islam). 
Penetapan hukum pelarangan aborsi, terdapat sedikit perbedaan dari keempat mazhab besar fiqih Islam, yaitu sebagai berikut:

1. Mazhab Hanafi berpendapat bahwa aborsi bisa dilakukan hanya bila membahayakan dan mengancam keselamatan si ibu dan hanya dapat dilakukan sebelum masa empat bulan kehamilan.

2. Mazhab Maliki melarang aborsi apabila telah terjadi pembuahan.

3. Mazhab Syafii berpaham apabila setelah terjadinya fertilisasi zygote, tidak boleh diganggu. Jika diganggu, dianggap sebagai kejahatan.

4. Mazhab Hambali berpendapat karena adanya pendarahan yang menimbulkan kematian, hal ini menunjukkan bahwa aborsi adalah dosa.

Dari pandangan mazhab manapun, jelas menyatakan bahwa aborsi dalam pandangan agama Islam tidak diperkenankan dan merupakan dosa besar karena dianggap membunuh nyawa manusia yang tidak bersalah. Pelakunya bisa diminta pertanggungjawaban atas tindakannya itu.

Hukum Islam yang telah tercatat ini menandakan bahwa janin dianggap sebagai manusia. Menyakiti atau membunuhnya termasuk dosa besar dan haram. Aborsi hanya boleh dilakukan apabila kehamilan tersebut dapat mengancam dan membahayakan jiwa si ibu, yang dianut mazhab Hanafi, dengan syarat usia kandungan belum mencapai 4 bulan. Meskipun demikian, Majelis Ulama Indonesia telah mengeluarkan fatwa bahwa wanita korban pemerkosaan dibolehkan melakukan aborsi (tindakan pengguguran janin), dengan syarat masa kehamilan belum mencapai 40 hari. Hal tersebut diperbolehkan karena korban perkosaan adalah orang yang teraniaya dan kehamilan bukan kehendaknya untuk melakukan hubungan tersebut, melainkan tindakan paksaan orang lain.

Agama Islam memberi aturan bagi umat muslim dalam rangka kehidupan dan peradaban yang lebih baik. Tak terkecuali dalam hal pengguguran kandungan yang disengaja atau aborsi. Hukum aborsi menurut Islam jelas keharamannya karena janin bayi yang berada dalam rahim seorang ibu telah mempunyai nyawa. Penghilangan terhadap nyawa seseorang adalah pembunuhan. 
Dari keterangan di atas, bisa diambil kesimpulan bahwa para ulama sepakat bahwa Abortus Profocatus Criminalis, yaitu aborsi kriminal yang menggugurkan kandungan setelah ditiupkan roh ke dalam janin tanpa suatu alasan syar'i hukumnya adalah haram dan termasuk katagori membunuh jiwa yang diharamkan Allah swt. Menurut Al Maliki dalam kitab Adabul Islam Fi Nidzami Usrah (1401 H:169) perdebatan mengenai boleh tidaknya menggugurkan kandungan sebagaimana diuraikan di atas, khususnya dari madzhab empat menyepakati bahwa aborsi yang dilakukan setelah bernyawa (ba'da nafkhi al-ruh) merupakan tindakan yang diharamkan.

\section{Hukum Tentang Aborsi di Indonesia}

Di Indonesia adapun ketentuan-ketentuan yang berkaitan dengan soal aborsi dan penyebabnya dapat dilihat pada:

1. KUHP Bab XIX Pasal 229,346 s/d 349:

Pasal 229: Barang siapa dengan sengaja mengobati seorang perempuan atau menyuruhnya supaya diobati, dengan diberitahukan atau ditimbulkan harapan, bahwa karena pengobatan itu hamilnya dapat digugurkan, diancam dengan pidana penjara paling lama empat tahun atau denda paling banyak tiga ribu rupiah.

Pasal 346: $\quad$ Seorang perempuan yang dengan sengaja menggugurkan atau mematikan kandungannya atau menyuruh orang lain untuk itu, diancam dengan pidana penjara paling lama empat tahun.

Pasal 347:(1) Barang siapa dengan sengaja menggugurkan atau mematikan kandungan seorang perempuan tanpa persetujuannya, diancam dengan pidana penjara paling lama dua belas tahun.

(2) Jika perbuatan itu mengakibatkan matinya perempuan tersebut, diancam dengan pidana penjara paling lama limabelas tahun.

Pasal 348:(1) Barang siapa dengan sengaja menggugurkan atau mematikan kandungan seorang perempuan dengan persetujuannya, diancam dengan pidana penjara paling lama lima tahun enam bulan. 
(2) Jika perbuatan itu mengakibatkan matinya perempuan tersebut, diancam dengan pidana penjara tujuh tahun.

Pasal 349: Jika seorang dokter, bidan atau juru obat membantu melakukan kejahatan berdasarkan pasal 346, ataupun membantu melakukan salah satu kejahatan dalam pasal 347 dan 348, maka pidana yang ditentukan dalam pasal itu dapat ditambah dengan sepertiga dan dapat dicabut hak untuk menjalankan pencaharian dalam mana kejahatan dilakukan.

Dari rumusan pasal-pasal tersebut dapat ditarik kesimpulan bahwa:

a. Seorang perempuan hamil yang dengan sengaja melakukan aborsi atau ia menyuruh orang lain, diancam hukuman empat tahun penjara.

b. Seseorang yang dengan sengaja melakukan aborsi terhadap ibu hamil dengan tanpa persetujuan ibu hamil tersebut, diancam hukuman penjara 12 tahun, dan jika ibu hamil tersebut mati, diancam penjara 15 tahun penjara.

c. Jika dengan persetujuan ibu hamil, maka diancam hukuman 5,5 tahun penjara dan bila ibu hamil tersebut mati diancam hukuman 7 tahun penjara.

d. Jika yang melakukan dan atau membantu melakukan aborsi tersebut seorang dokter, bidan atau juru obat ancaman hukumannya ditambah sepertiganya dan hak untuk berpraktik dapat dicabut.

e. Setiap janin yang dikandung sampai akhirnya nanti dilahirkan berhak untuk hidup serta mempertahankan hidupnya.

2. UU no. 23 tahun 1992 tentang kesehatan:

Pasal 75: (1) Setiap orang dilarang melakukan aborsi.

(2) Larangan sebagaimana dimaksud pada ayat (1) dapat dikecualikan berdasarkan: a. Indikasi kedaruratan medis yang dideteksi sejak usia dini kehamilan, baik yang mengancam nyawa ibu dan/ atau janin, yang menderita penyakit genetik berat 
dan/atau cacat bawaan, maupun yang tidak dapat diperbaiki sehingga menyulitkan bayi tersebut hidup di luar kandungan.

b. Kehamilan akibat perkosaan yang dapat menyebabkan trauma psikologis bagi korban perkosaan.

(3). Tindakan sebagaimana dimaksud pada ayat (2) hanya dapat dilakukan setelah melalui konseling dan/atau penasehatan pra tindakan dan diakhiri dengan konseling pasca tindakan yang dilakukan oleh konselor yang kompeten dan berwenang.

(4). Ketentuan lebih lanjut mengenai indikasi kedaruratan medis dan perkosaan, sebagaimana dimaksud pada ayat (2) dan ayat (3) diatur dengan Peraturan Pemerintah.

Pasal 76: Aborsi sebagaimana dimaksud dalam Pasal 75 hanya dapat dilakukan:

a. sebelum kehamilan berumur 6 (enam) minggu dihitung dari hari pertama haid terakhir, kecuali dalam hal kedaruratan medis

b. oleh tenaga kesehatan yang memiliki keterampilan dan kewenangan yang memiliki sertifikat yang ditetapkan oleh menteri

c. dengan persetujuan ibu hamil yang bersangkutan

d. dengan izin suami, kecuali korban perkosaan

e. penyedia layanan kesehatan yang memenuhi syarat yang ditetapkan oleh Menteri.

Pasal 77: Pemerintah wajib melindungi dan mencegah perempuan dari aborsi sebagaimana dimaksud dalam Pasal 75 ayat (2) dan ayat (3) yang tidak bermutu, tidak aman, dan tidak bertanggung jawab serta bertentangan dengan norma agama dan ketentuan peraturan perundang-undangan.

Pada penjelasan UU Kesehatan pasal 77 disebutkan bahwa yang dimaksud dengan praktik aborsi yang tidak bermutu, tidak aman, 
dan tidak bertanggung jawab adalah aborsi yang dilakukan dengan paksaan dan tanpa persetujuan perempuan yang bersangkutan, yang dilakukan oleh tenaga kesehatan yang tidak profesional, tanpa mengikuti standar profesi dan pelayanan yang berlaku, diskriminatif, atau lebih mengutamakan imbalan materi dari pada indikasi medis. Namun sayangnya didalam UU Kesehatan ini belum disinggung soal masalah kehamilan akibat hubungan seks komersial yang menimpa pekerja seks komersial. Dalam peraturan pemerintah sebagai pelaksanaan dari pasal ini dijabarkan antara lain mengenai keadaan darurat dalam menyelamatkan jiwa ibu hamil atau janinnya, tenaga kesehatan yang mempunyai keahlian dan kewenangan bentuk persetujuan, sarana kesehatan yang ditunjuk.

3. UU no 23 tahun 2004 tentang Penghapusan KDRT:

Pasal 10 mengenai hak-hak korban pada butir (b) disebutkan bahwa korban berhak mendapatkan pelayanan kesehatan sesuai dengan kebutuhan medis.

Dari sini dicoba disimpulkan sesuatu dan mempunyai persepsi dari pernyataan butir-butir pasal UU KDRT sebelumnya yang saling berkaitan:

1. Pasal 2(a): Lingkup rumah tangga ini meliputi: suami, istri, anak.

2. Pasal 5: Setiap orang dilarang melakukan kekerasan dalam rumah tangga terhadap orang dalam lingkup rumah tangganya dengan cara:
a. Kekerasan fisik
b. Kekerasan psikis
c. Kekerasan seksual
d. Penelantaran rumah tangga

3. Pasal 8(a) tentang kekerasan seksual meliputi:

a. Pemaksaan hubungan seksual yang dilakukan terhadap orang yang menetap dalam lingkup rumah tangga tersebut.

b. Pemaksaan hubungan seksual terhadap salah seorang dalam lingkup rumah tangganya dengan orang lain untuk tujuan komersil dan/atau tujuan tertentu. 
Dalam UU ini memang tidak disebutkan secara tegas apa yang dimaksud dengan 'pelayanan kesehatan sesuai dengan kebutuhan medis' pada pasal 10, namun apabila dikaitkan dengan kekerasan seksual yang berefek pada kehamilan yang tidak diinginkan, maka korban diasumsikan dapat meminta hak atas pelayanan medis untuk mengakhiri kehamilannya, karena secara medis, korban akan mengalami stres ataupun depresi, dan bukan tidak mungkin akan menjadi sakit jiwa apabila kehamilan tersebut diteruskan.

Dari penjelasan tersebut, didapatkan gambaran mengenai aborsi legal dan ilegal. aborsi provokatus/buatan legal yaitu aborsi buatan yang sesuai dengan ketentuan-ketentuan sebagaimana diatur dalam UU Kesehatan, yaitu memenuhi syarat sebagai berikut:

a. Berdasarkan indikasi medis yang kuat yang mengharuskan diambilnya tindakan tersebut;

b. Oleh tenaga kesehatan yang mempunyai keahlian dan kewenangan

c. Dengan persetujuan ibu hamil yang bersangkutan atau suami ataupun keluarganya

d. Pada sarana kesehatan tertentu.

Setiap dokter pada waktu baru lulus bersumpah untuk menghormati hidup mulai sejak saat pembuahan, karena itu hendaknya para dokter agar selalu menjaga sumpah jabatan dan kode etik profesi dalam melakukan pekerjaannya. Namun pada kehidupan sehari-hari, banyak faktor-faktor yang berperan, seperti rasa kasihan pada perempuan yang mengalami kehamilan yang tidak diinginkan, faktor kemudahan mendapatkan uang dari praktik aborsi yang memakan biaya tidak sedikit ataupun faktor-faktor lainnya.

Sejak abad 5 SM, Hipokrates sudah bersumpah antara lain bahwa ia "tidak akan memberikan obat kepada seorang perempuan untuk menggugurkan kandungannya". Sumpah itu kemudian kemudian menjadi dasar bagi sumpah dokter sampai sekarang. Pernyataan Geneva yang dirumuskan pada tahun 1984 dan memuat sumpah dokter antara lain menyatakan bahwa para dokter akan "menghormati setiap hidup insani mulai dari saat pembuahan". Pernyataan itu juga termuat dalam sumpah dokter Indonesia yang dirumuskan dalam PP no.26/1960.

Sikap para dokter se-dunia terhadap pengguguran terutama dirumuskan dalam "Pernyataan Oslo" pada tahun 1970, yang terutama 
menyoroti hal pengguguran berdasarkan indikasi medis. Rumusan itu berbunyi "Prinsip moral dasar yang menjiwai seorang dokter ialah rasa hormat terhadap kehidupan manusia sebagaimana diungkapkan dalam sebuah pasal Pernyataan Geneva: "Saya akan menjujung tinggi rasa hormat terhadap hidup insani sejak saat pembuahan".

Keadaan yang menimbulkan pertentangan antara kepentingan vital seorang ibu dan kepentingan vital anaknya yang belum dilahirkan ini menciptakan suatu dilema dan menimbulkan pertanyaan: "Apakah kehamilan ini harusnya diakhiri dengan sengaja atau tidak?". Perbedaan jawaban atas keadaan ini dikarenakan adanya perbedaan sikap terhadap hidup bayi yang belum dilahirkan. Perbedaan sikap ini adalah soal keyakinan pribadi dan hati nurani yang harus dihormati. Bukanlah tugas profesi kedokteran untuk menentukan sikap dan peraturan negara atau masyarakat manapun dalam hal ini, tetapi justru adalah kewajiban semua pihak mengusahakan perlindungan bagi pasien-pasien dan melindungi hak dokter di tengah masyarakat. Oleh sebab itu di mana hukum memperbolehkan pelaksanaan pengguguran terapetis, atau pembuatan UU ke arah itu sedang dipikirkan, dan hal ini tidak bertentangan dengan kebijaksanaan dari ikatan dokter nasional, serta dimana dewan pembuat undang-undang itu ingin atau mau mendengarkan petunjuk dari profesi medis, maka prinsip-prinsip berikut ini diakui:

a. Pengguguran hendaklah dilakukan hanya sebagai suatu tindakan terapetis.

b. Suatu keputusan untuk menghentikan kehamilan seyogyanya sedapat mungkin disetujui secara tertulis oleh dua orang dokter yang dipilih berkat kompetensi profesional mereka.

c. Prosedur itu hendaklah dilakukan oleh seorang dokter yang kompeten dalam instalasi-instalasi yang disetujui oleh suatu otoritas yang sah.

d. Jika seorang dokter merasa bahwa keyakinan hati nuraninya tidak mengizinkan dirinya menganjurkan atau melakukan pengguguran, ia berhak mengundurkan diri dan menyerahkan kelangsungan pengurusan medis kepada koleganya yang kompeten. 
Meskipun pernyataan ini didukung oleh "General Assembly of The World Medical Association", namun tidak perlu dipandang sebagai mengikat ikatan-ikatan yang menjadi anggota, kecuali kalau hal itu diterima oleh ikatan itu. Karenanya dihimbau bagi para dokter ataupun tenaga kesehatan lainnya agar:

1. Tindakan aborsi hanya dilakukan sebagai suatu tindakan terapeutik.

2. Suatu keputusan untuk menghentikan kehamilan, sedapat mungkin disetujui secara tertulis oleh minimal dua orang dokter yang kompeten dan berwenang.

3. Prosedur tersebut hendaknya dilakukan oleh seorang dokter yang kompeten di instansi kesehatan tertententu yang diakui oleh suatu otoritas yang sah.

4. Jika dokter tersebut merasa bahwa hati nuraninya tidak sanggup melakukan tindakan pengguguran, maka hendaknya ia mengundurkan diri serta menyerahkan pelaksanaan tindakan medis ini pada teman sejawat lainnya yang juga kompeten

5. Selain memahami dan menghayati sumpah profesi dan kode etik, para dokter dan tenaga kesehatan juga perlu meningkatkan pemahaman agama yang dianutnya.

Pada beberapa negara seperti Singapura, Cina, dan Tunisia, aborsi dilegalkan oleh pemerintahnya masing-masing dengan tujuan untuk membatasi pertumbuhan guna meningkatkan kesejahteraan. Negara Swedia, Inggris, dan Italia atas dasar sosiomedik, sedangkan di Jepang atas dasar sosial.

Dalam perundang-undangan Indonesia, pengaturan tentang aborsi terdapat dalam dua undang-undang yaitu KUHP dan UU Kesehatan. Dalam KUHP dan UU Kesehatan diatur ancaman hukuman melakukan aborsi (pengguguran kandungan, tidak disebutkan soal jenis aborsinya), sedangkan aborsi buatan legal (terapetikus atau medisinalis), diatur dalam UU Kesehatan.

Penghayatan dan pengamalan sumpah profesi dan kode etik masingmasing tenaga kesehatan, secara tidak langsung dapat mengurangi terjadinya aborsi buatan ilegal, lebih lagi jika diikuti dengan pendalaman dan pemahaman ajaran agama masing-masing. (billy@hukum-kesehatan.web.id) 


\section{Penutup}

Dengan demikian, aborsi secara umum merupakan perbuatan keji, tidak berperikemanusiaan dan bertentangan hukum dan ajaran agama. Walaupun demikian, hukum Aborsi secara khusus perlu dikaji secara lebih mendalam, karena Aborsi bukanlah dalam satu bentuk tindakan, tetapi juga mempunyai berbagai macam alasan. Sementara itu Islam bukanlah agama yang kaku, tetapi agama yang memandang kehidupan manusia ini dari berbagai sudut, sehingga ditemukan di dalamnya solusi atas segala problematika yang dihadapi oleh manusia, termasuk solusi masalah aborsi. Dalam perundang-undangan Indonesia, pengaturan tentang aborsi terdapat dalam dua undang-undang yaitu KUHP dan UU Kesehatan. Dalam KUHP dan UU Kesehatan diatur ancaman hukuman melakukan aborsi (pengguguran kandungan, tidak disebutkan soal jenis aborsinya), sedangkan aborsi buatan legal (terapetikus atau medisinalis), diatur dalam UU Kesehatan.

\section{DAFTAR PUSTAKA:}

Al Qur'anul Karim, 2008. Bandung: CV Diponegoro

Al-Maliki, Muhammad bin Alawi. 1401 H. Adabul Islam fi Nidzami Usroh. Jeddam Sahar

Anonymous. 2008. Hukum Aborsi Dalam Islam. http://www.ahmadzain. com/read/karya-tulis/258/hukum-aborsi-dalam-islam. Diakses 14 April 2012

Anonymous. 2009. Aborsi Secara Medis dan Moral.. http://stupidforwriting. blogspot.com/2009/11/aborsi-secara-medis-dan-moral.html. Diakses 11 April 2012

Anonymous. 2012. Gugur Kandungan.http://id.wikipedia.org. Diakses tanggal 11 Mei 2012

Anonymous..2008. Statistik aborsi di Indonesia. http://aborsi.net/info/ statistik-aborsi.html . Diakses 11 Mei 2012

Anonymous.2007. Aborsi di Indonesia.http://www.kesrepro.info. Diakses tanggal 8 Mei 2012

Anonymous.2012. Ayah Kandung Bayi Sudah Bisa Diketahui Saat Ibu 
hamil 3 Bulan. http://health.detik.com/ read/2012/05/03/093123 /1907791/1299/ayah kandung bayi sudah bisa diketahui saat ibu hamil 3 bulan?d8833health. Diakses 15 Mei 2012

Anshor, Maria Ulfa. 2006. Fikih Aborsi. Jakarta: Gramedia

Aslim, Setiawan. 17/1/1998. Aborsi Ditinjau Dari Sudut Medik. Majalah Kairos Humas UKRIDA

Billy N. 2010. Hukum Aborsi Di Indonesia. http://hukumkes.wordpress. com/2010/12/16/aborsi menurut hukum di indonesia/\#more10. Diakses 23 Mei 2012

Danis, Difa. Kamus Istilah Kedokteran, Gitamedia Press

Jhon M. Echols dan Hasan Shadily. 2003. Kamus Indonesia-Inggris. Jakarta:Gramedia

K. Bertens. Aborsi Sebagai Masalah Etika. 2003. Jakarta: Grasindo

Nusantara, Arjuna:23/04/2012. Jangan Jadi Kartini. Opini Harian Pagi Padang Ekspress

Sabiq, Sayyid, 1984. Fikih sunnah Jilid X. Bandung: Penerbit Al Ma'arif

Shannon, Thomas. A. Pengantar Bioetika. 1995. Jakarta: Gramedia

Tim Penyusun Kamus Pusat Bahasa. 2008. Kamus Besar Bahasa Indonesia, Jakarta: Balai Pustaka 